\title{
Managerial ability and intellectual capital disclosure
}

\author{
Javad Rajabalizadeh \\ Department of Accounting and Finance, Turku School of Economics, \\ University of Turku, Turku, Finland, and \\ Javad Oradi \\ Faculty of Economics and Administrative Sciences, Ferdowsi University of Mashhad, \\ Mashhad, Iran
}

Received 22 November 2020

Revised 18 April 2021

18 September 2021

Accepted 24 September 2021

\begin{abstract}
Purpose - While prior research in the area of intellectual capital (IC) disclosure has mainly focused on firm, board and audit committee characteristics, there is little research on whether managerial characteristics are associated with IC disclosure. This study aims to examine the relationship between managerial ability (MA) and the extent of IC disclosure.

Design/methodology/approach - The study sample comprises 1,098 firm-year observations of Iranian listed firms during 2012-2017. This study uses the checklist developed by Li et al. (2008) and adopts a content analysis approach and calculates the IC disclosure index in 62 dimensions within three categories: human capital, structural capital and relational capital. To measure MA, this study uses the managerial ability score (MA-Score) developed by Demerjian et al. (2012) for Iranian firms.

Findings - The results show that MA is significantly and negatively associated with the overall extent of IC disclosure and all the three components of IC (human capital, structural capital and relational capital). Further analysis shows that the interaction between MA and firm performance is positive and significant, suggesting that the negative relationship between MA and IC disclosure is less pronounced for high-performing firms. This study addresses the potential endogeneity issue by using the propensity score matching approach. The findings are also robust to the alternative measure of MA.

Originality/value - This study contributes to both the MA literature and the IC disclosure literature. To the best of the authors' knowledge, this study is the first to provide empirical evidence on the relationship between MA and IC disclosure.
\end{abstract}

Keywords Managerial ability, Corporate reporting, Intellectual capital disclosure, Agency conflicts, Corporate governance, Emerging market

Paper type Research paper

\section{Introduction}

Companies have been generating value not only from securities and financial assets but also from intangible assets, such as the skills of employees (human capital), technological innovation and breakthroughs (structural capital) and relationships with customers (direct relational capital), all of which are forms of potential intellectual capital (IC) (Su, 2014; CruzGonzález et al., 2014; Rossi et al., 2021). The existing literature suggests that IC plays a significant role in improving the efficiency of both capital and labor markets (Petty and Guthrie, 2000; Bismuth and Tojo, 2008) and increasing the performance and wealth of organizations (Dumay and Roslender, 2013; Muttakin et al., 2015). Some studies have benefited from stakeholder theory to highlight the usefulness of IC information disclosure and argues that it can reduce the asymmetric information and increases accountability

(C) Javad Rajabalizadeh and Javad Oradi. Published by Emerald Publishing Limited. This article is published under the Creative Commons Attribution (CC BY 4.0) licence. Anyone may reproduce, distribute, translate and create derivative works of this article (for both commercial and non-commercial purposes), subject to full attribution to the original publication and authors. The full terms of this licence may be seen at http://creativecommons.org/licences/by/4.0/legalcode

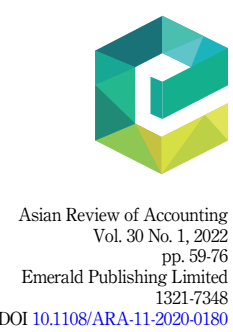


ARA

30,1
(Yi and Davey, 2010; Mangena et al., 2014; Nadeem, 2020). Moreover, the nondisclosure of IC information may lead to the higher cost of equity, increased earnings uncertainty and more significant distortions in earnings forecasts (Barus and Siregar, 2014; Boujelbene and Affes, 2013; Orens et al., 2013; Kristandl and Bontis, 2007). Therefore, if firms disclose IC information, stakeholders' ability to evaluate the firm's capacity in terms of long-term value creation will be increased. However, the disclosure of IC information is voluntary, and an integrated IC reporting system in which (individual) investors can make better decisions about investments has not yet been developed.

Research on IC disclosure has mostly focused on firm-level and board/audit committee characteristics (e.g. Li et al., 2008; Hidalgo et al., 2011; Li et al., 2012; Haji, 2015). However, evidence on whether top managers' characteristics are associated with IC disclosure is limited. This study extends the current literature by examining whether managerial ability (MA) (described as a manager's relative efficiency and capacity to convert resources into revenue) is associated with the extent of IC disclosure in an emerging market (Iran). We also examine the relationship between MA and the extent of IC disclosure in the three components of IC: human capital, structural capital and relational capital.

Upper echelons theory suggests that differences in managers' values and cognitive styles lead to their distinct decisions (Hambrick and Mason, 1984), particularly in complex situations (Bamber et al., 2010). This theory explains that top managers' characteristics affect financial and nonfinancial outcomes (Hambrick and Mason, 1984; Hambrick, 2007). Therefore, we expect that MA as an important managerial characteristic (Demerjian et al., 2013) will affect the disclosure of nonfinancial information. Prior studies indicate that MA has a positive effect on firm performance and the quality of disclosed information (e.g. Holcomb et al., 2009; Demerjian et al., 2013; Chen and Chen, 2020; Hasan, 2020). Since IC disclosure is crucial to create firm value (Nadeem, 2020), able managers may disclose IC information to signal their firms' good performance and sustainable competitive advantages.

However, in emerging markets such as Iran, where there are not strong monitoring mechanisms (both in the firm and capital market levels) (Oradi, 2021), agency problems would be more severe, and managers' personal goals might be in conflict with stakeholders' interests (Jensen and Meckling, 1976). In particular, top managers in Iran face fewer limitations and have greater discretion as to how much information they disclose to stakeholders compared with their counterparts in developed countries with effective monitoring systems (Oradi et al., 2020). Thus, they might decrease the level of disclosures to protect their own benefits, resulting in lower IC information disclosure. Furthermore, top managers in such an environment are less likely to be concerned about firm-specific risk and are more likely to participate in a value-destroying operation.

We use a unique hand-collected dataset of firms listed on the Tehran Stock Exchange (TSE) over the time window 2012-2017. Based on a content analysis, we calculate the IC disclosure index in 62 dimensions within three categories: human capital, structural capital and relational capital disclosure (Li et al., 2008). To measure MA, we use the managerial ability score (MA-Score) developed by Demerjian et al. (2012). Using 1,098 firm-year observations, we find that MA is significantly and negatively associated with the overall IC disclosure and all the three components of IC (human, structural and relational capital). The results are robust to the endogeneity test and the alternative measure of MA. Moreover, additional analysis shows that the negative relationship between MA and IC disclosure is less pronounced for firms with high profitability. In particular, the results of this study demonstrate that MA plays a major role in corporate reporting processes in an emerging market.

This study contributes to the literature on both MA and IC disclosure in several ways. First, this is the first study to investigate the relationship between MA and IC disclosure, and thus, this study adds to the extant literature. Second, this study provides a better 
understanding of how MA affects the level of corporate disclosures in an emerging economy context. Our findings are consistent with principal-agent and proprietary cost theories, according to which MA might not serve as a useful internal governance mechanism in an emerging market such as Iran. Further analyses show that, consistent with agency theory, higher profitability can mitigate the negative impact of MA on IC disclosure, suggesting that lower agency costs can improve the level of disclosures by top managers. Third, most studies on IC disclosure have concentrated on developed countries such as the USA and the UK, where ownership structure is more diffused, and thus, governance structures enjoy ongoing oversight. Therefore, this study is one of the earliest attempts in the context of an emerging economy. Finally, IC information disclosure is of crucial importance to market participants because it shows a firm's true value and transparency level. Therefore, our study informs participants in Iran's capital market and other similar emerging markets about the role of managerial characteristics in IC disclosure.

The remainder of this paper is organized as follows. Section 2 reviews related literature and discusses the institutional characteristics of Iran, and then develops the research hypothesis. Section 3 presents the research design, including the sample selection procedure, the measurement of the dependent and primary independent variables and the model specification. Section 4 reports empirical results, including main results, robustness tests and additional analyses. Finally, Section 5 concludes the paper.

\section{Literature review, institutional context and hypothesis development \\ 2.1 Literature review}

Today, IC plays a crucial role in enhancing the value of organizations in knowledge-based economies (Edvinsson, 2013). The success of organizations is related to their ability to extract value from their IC to gain maximum organizational benefits (Muttakin et al., 2015). In particular, IC information as one of the critical items of nonfinancial information plays an essential role in stakeholders' decisions (Li et al., 2008) and reveals the actual value of a firm via identifying new or hidden relations among different types of assets (Haji, 2015). Accordingly, the release of IC information has attracted attention from academics, regulators and stock market participants (Li et al., 2012). However, there is still no explicit regulation on IC reporting, and therefore, IC-related information is voluntarily disclosed (Dumay and Cai, 2014). This inconsistency causes difficulties for investors in evaluating firms, resulting in a lower amount of information concerning the value of IC investments. Accordingly, enhancing IC disclosures may result in a lower degree of information asymmetry between managers and investors and lead to a more accurate firm valuation (Holland, 2003; Li et al., 2012). Prior literature suggests that a greater degree of IC information disclosure leads to a lower cost of capital (Kristandl and Bontis, 2007; Garanina and Dumay, 2017; Salvi et al., 2020) and increased stock market value (Bismuth and Tojo, 2008). Previous studies have also documented the determining factors of IC disclosure such as firm-specific characteristics (size, performance, complexity, etc.) (e.g. Striukova et al., 2008; Maaloul and Zéghal, 2015; Goebel, 2019; Sriram, 2020) and corporate governance structure (board and audit committee characteristics) (e.g. Cerbioni and Parbonetti, 2007; Li et al., 2012; Muttakin et al., 2015; Haji, 2015; Tejedo-Romero et al., 2017; Nadeem, 2020). Nevertheless, there is limited research on the impact of managerial characteristics on voluntary IC disclosure.

MA as an essential managerial characteristic mostly stems from a manager's knowledge of the market, corporate plans and technology (Boeker, 1989; Kor, 2003). Capable managers are better at understanding technological and market dynamics, forecasting the product market accurately, investing in high profitable projects and managing employees compared with their counterparts (Demerjian et al., 2012). High-ability managers may gain more accurate information about investment opportunities, allowing them to make informed investment 
ARA

30,1

\section{2}

decisions with a higher chance of success (Hasan, 2020). Since more able managers have a greater knowledge of the drivers of firm performance, they can better respond to economic pressures and the competitive market (Cui et al., 2019; Hui and Matsunaga, 2015; BarrenaMartínez et al., 2019), better utilize organizational resources (Demerjian et al., 2013), have a higher capability to deal with environmental uncertainty and grasp favorable investment opportunities (Yuan et al., 2017). Therefore, able managers are more likely to adopt innovative strategies, which may affect their risk-taking and interpretation of and response to environmental conditions (Tang et al., 2015; Chen et al., 2015; Yung and Chen, 2018). Extensive research in the fields of management, accounting and finance investigates the consequences of MA. For example, Demerjian et al. (2013) show that earnings quality is influenced by managerial abilities, and more able managers, who are highly knowledgeable about technology and operations, have greater abilities to forecast earnings. Furthermore, higher-ability managers are linked to a higher level of earnings smoothing (Demerjian et al., 2020). Baik et al. (2011) find that MA is positively associated with corporate social responsibility, suggesting that managers with higher ability have more influence on firms' corporate social responsibility (CSR) performance. Koester et al. (2017) report that there is a significant relationship between managerial abilities and corporate tax avoidance activities. Chemmanur and Paeglis (2005) find that high-ability managers can improve firm performance because they may choose more profitable projects using initial public offering (IPO) proceeds. The findings of these studies mainly support upper echelons theory suggesting that MA affects corporate performance and reporting decisions (Hambrick and Mason, 1984; Hambrick, 2007).

\subsection{Institutional context and hypothesis development}

Although prior literature indicates that firms with able managers experience higher-quality disclosures and better performance, we argue that the consequences of able managers can be different depending on a country's institutional background, in our case, Iran. Similar to other emerging markets, the corporate sector in Iran is characterized by high ownership concentration, insufficient laws and regulations and relatively weak investor protection (Mashayekhi and Bazaz, 2008; Hesarzadeh and Rajabalizadeh, 2019), which leads to corporate governance failure in listed companies (Oradi et al., 2021). Moreover, managers in Iranian firms experience fewer limitations and have lower compensation incentives than managers in developed countries with appropriate corporate governance practices. Thus, they have more freedom to play according to their characteristics and preferences, which affects the level of information disclosure. Agency theory states that managers may make decisions that help them pursue their own interests and ignore those of shareholders (Jensen and Meckling, 1976). According to this theory, potential conflicts of interests between managers and shareholders are generally due to the inability of owners to monitor managers effectively (Cerbioni and Parbonetti, 2007). Prior literature suggests that voluntary disclosures help to reduce information asymmetries and consequently agency conflicts, and weak corporate governance practices dissuade managers from disclosing IC information (e.g. Cerbioni and Parbonetti, 2007; Li et al., 2012; Haji, 2015). In other words, weak corporate governance practices are the fundamental cause of managers' destructive behavior. Thus, in Iranian firms, the absence of strong monitoring mechanisms capable of protecting the interests of shareholders may induce able managers to disclose a lower degree of IC information so as to maximize their own benefits. Based on the above arguments, the research hypothesis is stated as follows:

H1. MA is negatively associated with the extent of IC information disclosure in the Iranian context.

We acknowledge that MA may be associated with a higher level of IC disclosure. For example, managers with higher abilities may have a tendency to disclose more IC information 
with the intention of displaying their better performance. In this regard, Hesarzadeh and Bazrafshan (2019) show that firms with able CEOs are less likely to receive comment letters from the Securities and Exchange Organization of Iran, especially when the level of agency conflicts is low and the quality of corporate governance is high.

\section{Research design}

\subsection{Sample selection}

The research sample comprises nonfinancial firms listed on the TSE over the period from 2012 to 2017. All the required data are manually extracted from the comprehensive database of the Securities and Exchange Organization of Iran [1] (CODAL). We exclude delisted firms and firm-years with missing data required for running research models. Ultimately, after excluding the delisted firms and missing data, the final research sample consists of a crosssectional time-series data set, including 1,098 firm-year observations from 183 firms (a balanced panel _ 6 years *183 firms). Table 1 presents the sampling procedure and the sample breakdown by industry.

\subsection{Measurement of IC disclosure}

Following previous studies (e.g. Li et al., 2012), we use the content analysis approach and the checklist developed by Li et al. (2008) to measure the extent of IC disclosure. Li et al. (2008) developed a comprehensive list of IC information, including 61 disclosure items that fall into human capital, structural capital and relational capital categories (see Table 2). Notably, unlike other IC disclosure checklists presented in previous studies (e.g. Bukh et al., 2005), the mentioned checklist is more relevant to the Iranian environment and has been used in previous studies in Iran (Rahmani et al., 2014). Most of the prior IC disclosure research has used binary coding, which indicates the existence or nonexistence of IC items, to measure IC disclosure (e.g. Petty and Guthrie, 2000; Li et al., 2008; Garanina and Dumay, 2017; Nadeem,

Panel A. Sample selection procedure

Description

Observations

Number of nonfinancial firms observations for the period 2012-2017

Less: firms that are not continuously

1,554

Less: missing data

Final sample

1,098

\section{Panel B. Sample firm break down by industry}

Industry

Car

Nonmetallic minerals

Cement

Basic metals

Tile

Tire

Machinery

Chemical products

Food

Drug

Metallic minerals

Others

Total

No. of firm-year observations

$\%$ Sample

$\begin{array}{rr}168 & 15.30 \\ 48 & 4.37 \\ 96 & 8.74 \\ 108 & 9.84 \\ 42 & 3.83 \\ 36 & 3.28 \\ 84 & 7.65 \\ 78 & 7.10 \\ 78 & 7.10 \\ 132 & 12.02 \\ 42 & 3.83 \\ 186 & 16.94 \\ 1,098 & 100.00\end{array}$

MA and IC disclosure

\section{$-$}


ARA

30,1

Panel A. Variables names, measures and source of information

Variable acronym Measure

Dependent variable

IC disclosure index

IC disclosure index based on Li et al. (2008). The overall IC disclosure index (IC) is computed as the number of format items disclosed in the annual report divided by 61 . The overall disclosure index is split into its three components: Human capital disclosure (HIC), structural capital disclosure (SIC) and relational capital disclosure (RIC)

\section{4}

Independent variable

MA

Control variables

FSIZE

LEV

Managerial ability-score from Demerjian et al. (2012)

Natural logarithm of the client's total assets

Total debt scaled by lagged total assets

PROFITABILITY

LNAGE

BOARDSIZE

BOARDIND

BOARDGD

FAMILY

CONOWN

Net income after tax divided by the total assets

The natural logarithm of number of years the firm is establishment

The number of directors on the board of directors

The percentage of independent directors on the board of directors

1 if there is a female member on the board, otherwise 0

The percentage of the firm's shares held by family members

The percentage of a firm's outstanding shares that are owned by the largest shareholder

Additional variables

MA-Rank

The decile rank (by industry and year) of managerial ability

MA dummy

Source

Annual reports

(AR)

AR

AR

AR

AR

AR

$\mathrm{AR}$

AR

$\mathrm{AR}$

AR

AR

AR

AR

AR

Panel B. IC disclosure items

Human capital

Structural capital

1. Number of employees

2. Employee age

3. Employee diversity

4. Employee equality

5. Employee relationship

6. Employee education

7. Skills/know-how/expertise/ knowledge

8. Employee work-related competences

9. Employee work-related knowledge

10. Employee attitudes/behavior

11. Employee commitments

12. Employee motivation

13. Employee productivity

14. Employee training

Table 2.

Variables definitions and research

instrument
15. Vocational qualifications

16. Employee development
1. Intellectual property

2. Process

3. Management philosophy

4. Corporate culture

5. Organization flexibility

6. Organization structure

7. Organization learning

8. Research and development

9. Innovation

10. Technology

11. Financial dealings

12. Customer support function

13. Knowledge-based infrastructure

14. Quality management and improvement

15. Accreditations (certificate)

16. Overall infrastructure/capability
Relational capital

1. Customers

2. Market presence

3. Customer relationships

4. Customer acquisition

5. Customer retention

6. Customer training and education

7. Customer involvement

8. Company image/reputation

9. Company awards

10. Public relation

11. Diffusion and networking

12. Brands

13. Distribution channels

14. Relationship with suppliers

15. Business collaboration

16. Business agreements 
Panel B. IC disclosure items

Human capital

17. Employee flexibility

18. Entrepreneurial spirit

19. Employee capabilities

20. Employee teamwork

21. Employee involvement with community

22. Other employee features

Source(s): Li et al. (2008)

MA and IC disclosure

Relational capital

17. Networking

18. Distribution network
17. Favorite contract

18. Research collaboration

19. Marketing

20. Relationship with

stakeholders

21. Market leadership

2020). We read through the annual reports (including financial statements and the board's reports) and manually extract the scores of firms' IC disclosure (1 if the firm discloses each item of the checklist, 0 otherwise). Finally, the score of IC disclosure for each firm is calculated by dividing the sum of disclosure scores by the total number of IC disclosure items. For each firm, we create four disclosure indices to capture the overall IC (IC), human capital (HIC), structural capital (SIC) and relational capital (RIC) disclosure. Regarding the collection of IC-related data, it should be noted that, at first, one of the researchers reviewed the financial statements and the board's reports of firms and carried out the process of the score assignment. Then, to enhance the reliability of the collected data, the other researcher randomly reviewed some of the financial statements and the board's reports of firms and checked the accuracy of the collected data. Furthermore, following Li et al. (2012), we compute Krippendorff's alpha (1980), which shows that the independent scores (not tabulated) are above $80 \%$, and the content analysis is highly reliable.

\subsection{Measurement of managerial ability}

We expect more able managers to maximize resource efficiency and generate higher revenue. The efficiency with which managers produce revenues is an intuitively appealing criterion for evaluating managers as it is the overriding objective of profit-maximizing firms (Demerjian et al., 2012). To measure MA, we use the approach of Demerjian et al. (2012) to generate our MA-Score for our sample of Iranian firms. To this end, we adopt a two-step procedure to measure MA. In the first step, using data envelopment analysis (DEA), a nonlinear optimization procedure for evaluating the decision-making efficiency, we estimate total firm efficiency by solving an optimization model where sales are the output, and there are seven input variables: (1) property, plant and equipment; (2) operating lease; (3) research and development costs; (4) purchased goodwill; (5) other intangible assets; (6) cost of goods sold and (7) selling, general and administrative expenses. By doing this, we can identify firms that generate the highest level of revenue from given inputs. In the second step, we estimate MA from the firm efficiency measure. As the latter reflects both firm-level and managerspecific efficiency drivers, we follow Demerjian et al. (2012) method at the second phase by estimating for each industry a regression of firm efficiency on six firm characteristics that affect firm efficiency: firm size, firm market share, cash availability, firm age, business segment concentration and foreign operations. The residual from this regression is the MAScore. It shows managers' ability to transform corporate resources into revenues compared with their industry counterparts. In the robustness tests, we use the decile rank (by industry and year) of MA-Sources as an alternative measure of MA (Demerjian et al., 2012, 2013; Huang and Sun, 2017; Hesarzadeh and Bazrafshan, 2019; Hasan, 2020). 
ARA

30,1

66
3.4 Model specification

The research hypothesis is tested using the following ordinary least squares (OLS) model:

$$
\begin{aligned}
& \mathrm{IC}_{i t}=\alpha_{0}+\alpha_{1} \mathrm{MA}_{i t}+\alpha_{2} \mathrm{FSIZE}_{i t}+\alpha_{3} \mathrm{LEV}_{i t}+\alpha_{4} \text { ROFITABILITY }_{i t} \\
& +\alpha_{5} \mathrm{LNAGE}_{i t}+\alpha_{6} \mathrm{BOARDSIZE}_{i t}+\alpha_{7} \mathrm{BOARDIND}_{i t}+\alpha_{8} \mathrm{BOARDGD}_{i t} \\
& +\alpha_{9} \mathrm{FAMILY}_{i t}+\alpha_{10} \mathrm{CONOWN}_{i t}+\mathrm{INDUSTRY}+\mathrm{YEAR}+\varepsilon_{i t}
\end{aligned}
$$

The dependent variable is IC, as the measure of the extent of IC disclosure. The main variable of interest is MA, as captured by the MA-Score. We control for several determinants of IC disclosure identified by prior research (e.g. Li et al, 2008; Cerbioni and Parbonetti, 2007; Li et al., 2012; Haji, 2015; Nadeem, 2020). First, we control for firm characteristics including firm size (FSIZE), leverage (LEV), return on assets (PROFITABILITY) and firm age (LNAGE). We also control for firms' corporate governance factors and ownership structures, including board size (BOARDSIZE), board independence (BOARDIND), board gender diversity (BOARDGD), family ownership (FAMILY) and concentration ownership (CONOWN). Finally, we include industry (INDUSTRY) and year (YEAR) dummies in the regression to control for industry and year effects. Table 2 provides the definitions for variables used in this paper.

\section{Empirical results}

\subsection{Descriptive analysis and correlations}

Table 3 provides descriptive statistics. The mean IC disclosure index (IC) is $37.6 \%$ in a range between 15.8 and $64.2 \%$. These findings are consistent with previous studies (e.g. Bozzolan et al., 2003; Striukova et al., 2008; Li et al., 2012; Nadeem, 2020) and demonstrate that IC information is not extensively disclosed in the firms' annual reports. Among IC items, the mean human capital disclosure item (HIC) is $39.9 \%$, which is significantly greater than the mean structural capital disclosure item (SIC) and the mean relational capital disclosure item (RIC) (35.2 and 34.4\%, respectively). Also, Table 3 shows that the mean value of MA is -0.005 , which is close to those reported in prior studies in the Iranian context (Hesarzadeh and Bazrafshan, 2019).

Regarding the control variables, the mean (median) values of firm size (FSIZE) and leverage (LEV) are 14.320 (14.055) and 59.2\% (59\%), respectively. Additionally, the means (medians) of return on assets (PROFITABILITY) and firm age (LNAGE) are 10.2\% (9.2\%)

\begin{tabular}{lrrrcrr}
\hline Variable & $N$ & \multicolumn{1}{c}{ Mean } & Median & Std. dev. & Max. & Min. \\
\hline IC & 1,098 & 0.376 & 0.361 & 0.099 & 0.642 & 0.158 \\
HIC & 1,098 & 0.399 & 0.412 & 0.127 & 0.680 & 0.143 \\
SIC & 1,098 & 0.352 & 0.330 & 0.127 & 0.719 & 0.170 \\
RIC & 1,098 & 0.344 & 0.328 & 0.131 & 0.686 & 0.102 \\
MA & 1,098 & -0.005 & -0.020 & 0.180 & 0.559 & -0.381 \\
FSIZE & 1,098 & 14.320 & 14.055 & 1.578 & 19.010 & 11.253 \\
LEV & 1,098 & 0.592 & 0.590 & 0.225 & 1.411 & 0.120 \\
PROFITABILITY & 1,098 & 0.102 & 0.092 & 0.135 & 0.514 & -0.258 \\
LNAGE & 1,098 & 3.582 & 3.690 & 0.391 & 4.140 & 2.641 \\
BOARDSIZE & 1,098 & 5.034 & 5.000 & 0.260 & 7.000 & 5.000 \\
BOARDIND & 1,098 & 0.678 & 0.600 & 0.190 & 1.000 & 0.200 \\
BOARDGD & 1,098 & 0.070 & 0.000 & 0.255 & 1.000 & 0.000 \\
FAMILY & 1,098 & 0.059 & 0.000 & 0.165 & 0.791 & 0.000 \\
CONOWN & 1,098 & 0.726 & 0.771 & 0.187 & 0.982 & 0.145 \\
Note(s): & & & & & &
\end{tabular}

Table 3.

Descriptive statistics

Note(s): This table presents summary statistics of variables used in main analyses. See Table 1 for variable definitions 
and 3.582 (3.690), respectively. The average board size (BOARDSIZE) is approximately 5.03 members, and $67.8 \%$ of directors are independent (BOARDIND). The mean board gender diversity (BOARDGD) in the sampled firms is $7.0 \%$. With regard to ownership structure, the results show that the mean percentages of family ownership (FAMILY) and ownership concentration $(\mathrm{CONOWN})$ are 5.9 and $72.6 \%$, respectively. The mean control variables are generally consistent with the previous studies in the Iranian context (Hesarzadeh et al., 2019; Oradi and Izadi, 2019; Hesarzadeh and Rajabalizadeh, 2019; Oradi et al., 2020).

Table 4 reports Pearson correlations among the variables. A significant negative correlation between MA and IC provides initial evidence that MA might have negative effects on IC disclosure. Regarding control variables, IC is positively correlated with FSIZE, LEV and CONOWN and negatively correlated with BOARDSIZE, BOARDIND and FAMILY (all significant at $p<0.01$ ). As each of the IC disclosure items (HIC, SIC, and RIC) is separately used in regression analyses, the high correlation among them does not raise concern regarding the potential effect of multicollinearity. To further check for the possibility of multicollinearity among the variables included in our models, we calculate the variance inflation factors (VIFs). The results (unreported) demonstrate that the highest VIF is below 2.5 , suggesting that multicollinearity is not a problem in our data.

\subsection{Regression results}

Table 5 presents the results of the relationship between MA and IC disclosure. Model 1 reports the results of the overall IC disclosure (IC) model, and Models 2, 3 and 4 report the results for the individual components of IC disclosure (namely HIC, SIC and RIC). The results of Column 1 show that MA is significantly and negatively associated with the overall IC disclosure (coefficient -0.043 with $t$-statistic -2.72 ), suggesting that MA significantly reduces IC. Thus, H1 regarding the relationship between MA and IC disclosure is supported. In economic terms, a $1 \%$ increase in MA results in a $0.04 \%$ decrease in IC disclosure. Regarding the individual components of IC disclosure, the results of Columns 2-4 of Table 5 indicate that MA is significantly and negatively associated with HIC, SIC and RIC.

With regard to control variables, we find that firm size (FSIZE), leverage (LEV), return on assets (PROFITABILITY) and ownership concentration (CONOWN) are significantly and positively associated with the overall IC disclosure and all the three IC disclosure components, while board size (BOARDSIZE) is significantly and negatively associated with the overall IC disclosure (IC), HIC and RIC, and family ownership (FAMILY) provides mixed results. These findings are generally consistent with previous studies on corporate governance and IC disclosure (e.g. Cerbioni and Parbonetti, 2007; Li et al., 2012; Haji, 2015).

\subsection{Interaction between managerial ability and firm performance}

Table 5 suggests that better-performing firms are more likely to disclose IC information. Thus, we investigate the moderating effect of profitability (PROFITABILITY) on the relationship between MA and IC disclosure. The IC and profitability relation can be defined based on the resource-based theory, according to which IC increases profitability and positively affects firm performance (Cuozzo et al., 2017). The resource-based theory suggests that utilizing tangible and intangible assets improves firm performance (Alfraih, 2018). Previous studies find a significant positive relationship between IC and profitability (Cheng et al., 2010; Mention and Bontis, 2013; Jordao and Almeida, 2017). Altogether, we expect the negative relationship between MA and IC disclosure to be less pronounced for betterperforming firms. We include an interaction term (MA*PROFITABILITY) in our main model and report the results in Table 6 . Consistent with our prediction, the coefficient on MA*PROFITABILITY is positive and significant (at the $5 \%$ level), showing that the MA-IC relation is less pronounced for firms with high levels of profitability. 
ARA
30,1

68

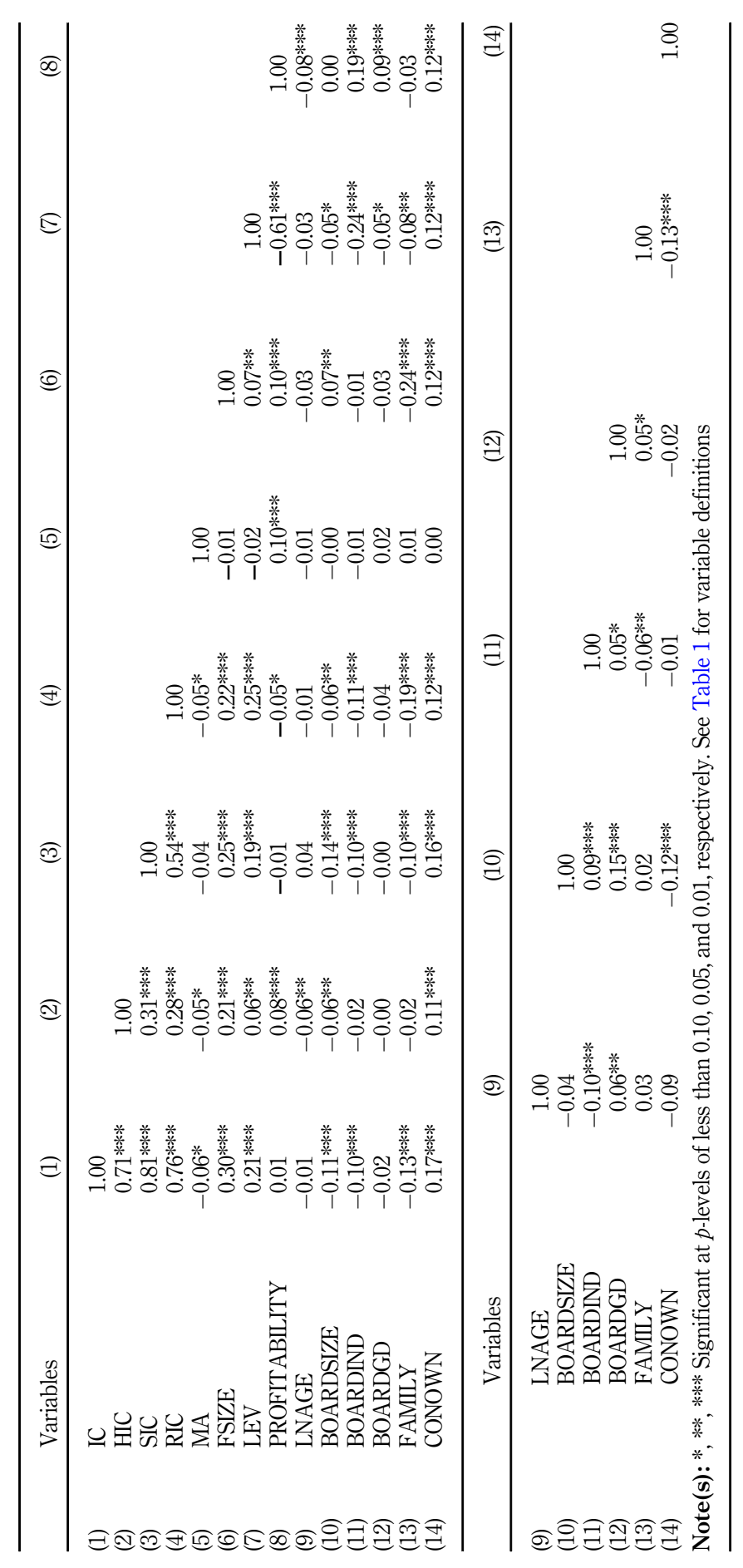

Table 4 .
Correlation analysis 


\begin{tabular}{|c|c|c|c|c|c|}
\hline & Model 1 IC & Model 2 HIC & Model 3 SIC & Model 4 RIC & \\
\hline MA & $-0.043 * * *(-2.72)$ & $-0.051^{* *}(-2.29)$ & $-0.039 *(-1.93)$ & $-0.039 *(-1.77)$ & \\
\hline FSIZE & $0.017 * * *(9.28)$ & $0.016^{* * *}(6.11)$ & $0.014 * * *(5.96)$ & $0.020^{* * *}(7.93)$ & \\
\hline LEV & $0.094 * * *(5.55)$ & $0.068^{* * * *}(2.90)$ & $0.109 * * *(5.17)$ & $0.106^{* * * *}(4.55)$ & \\
\hline PROFITABILITY & $0.105^{* * * *}(3.48)$ & $0.127 * * * *(2.99)$ & $0.092 * *(2.42)$ & $0.089 * *(2.14)$ & \\
\hline LNAGE & $-0.003(-0.47)$ & $-0.022^{* *}(-2.32)$ & $-0.004(-0.47)$ & $0.013(1.38)$ & \\
\hline BOARDSIZE & $-0.035^{* * *}(-3.43)$ & $-0.030 * *(-2.09)$ & $-0.010(-0.84)$ & $-0.064 * * *(-4.48)$ & 69 \\
\hline BOARDIND & $-0.014(-0.95)$ & $0.010(0.49)$ & $-0.002(-0.11)$ & $-0.043 * *(-2.12)$ & \\
\hline BOARDGD & $0.005(0.51)$ & $0.006(0.41)$ & $-0.007(-0.60)$ & $0.016(1.14)$ & \\
\hline FAMILY & $-0.026(-1.58)$ & $0.046^{*}(1.93)$ & $-0.107 * * *(-5.05)$ & $-0.039 *(-1.70)$ & \\
\hline CONOWN & $0.048^{* * *}(3.16)$ & $0.038^{*}(1.77)$ & $0.041^{* *}(2.12)$ & $0.063^{* * * *}(2.98)$ & \\
\hline CONSTANT & $0.224 * * *(3.37)$ & $0.312 * * *(3.35)$ & 0.119 (1.44) & $0.258 * * *(2.82)$ & \\
\hline Industry effects & Yes & Yes & Yes & Yes & \\
\hline Year effects & Yes & Yes & Yes & Yes & \\
\hline Adj. $R^{2}$ & 0.247 & 0.110 & 0.280 & 0.189 & \\
\hline$F(p$-value $)$ & $14.34(0.000)$ & $6.04(0.000)$ & $16.84(0.000)$ & $10.47(0.000)$ & \\
\hline Observations & 1,098 & 1,098 & 1,098 & 1,098 & Regression results: I \\
\hline \multicolumn{5}{|c|}{$\begin{array}{l}\text { Note(s): This table reports the results of the impact of managerial ability on intellectual capital disclosure. See } \\
\text { Table } 1 \text { for variable definitions. Absolute value of } t \text {-statistics in parentheses } \\
*, * * \text { and *** Significant at } p \text {-levels of less than } 0.10,0.05 \text { and } 0.01 \text {, respectively }\end{array}$} & $\begin{array}{r}\text { disclosure at both } \\
\text { overall and component } \\
\text { levels }\end{array}$ \\
\hline
\end{tabular}

\subsection{Robustness analyses}

4.4.1 Endogeneity test. The endogeneity issue, mainly in the empirical corporate governance research (Dittmar and Mahrt-Smith, 2007; Bhagat and Bolton, 2008), occurs when the explanatory variables and the error term are correlated in the regression model, leading to biased and inconsistent parameter estimates. Studies including those of Yermack (1996) and Himmelberg et al. (1999) carry out a fixed-effects panel specification to reduce estimation concerns linked to endogeneity. Supposing that the unobservable characteristics are fixed over time for a specific firm, the researcher can employ a fixed-effects panel model to obtain

\begin{tabular}{|c|c|c|c|}
\hline Dependent variable $=\mathrm{IC}$ & Coefficient & & $t$-statistic \\
\hline MA & $-0.068 * * *$ & & -3.47 \\
\hline PROFITABILITY & $0.111 * * *$ & & 3.64 \\
\hline MA*PROFITABILITY & $0.221^{* *}$ & & 2.17 \\
\hline FSIZE & $0.017^{* * * *}$ & & 9.41 \\
\hline LEV & $0.095^{* * * *}$ & & 5.65 \\
\hline LNAGE & -0.003 & & 0.53 \\
\hline BOARDSIZE & $-0.036^{* * *}$ & & 3.47 \\
\hline BOARDIND & -0.012 & & -0.85 \\
\hline BOARDGD & 0.005 & & 0.55 \\
\hline FAMILY & -0.026 & & -1.55 \\
\hline CONOWN & $0.048^{* * * *}$ & & 3.11 \\
\hline CONSTANT & $0.221 * * *$ & & 3.33 \\
\hline Industry effects & \multicolumn{3}{|c|}{ Yes } \\
\hline Year effects & \multicolumn{3}{|c|}{ Yes } \\
\hline Adj. $R^{2}$ & \multicolumn{3}{|c|}{0.249} \\
\hline$F(p$-value $)$ & \multicolumn{3}{|c|}{$14.05(0.000)$} \\
\hline Observations & \multicolumn{3}{|c|}{1,098} \\
\hline
\end{tabular}

Note(s): This table presents the results of the interaction between managerial ability and firm performance (PROFITABILITY). See Table 1 for variable definitions $*$, ** and *** Significant at $p$-levels of less than $0.10,0.05$ and 0.01 , respectively

Table 6.

Interaction between managerial ability and firm performance 
ARA

30,1

70 consistent parameter estimates robust to unobservable heterogeneity. However, fixed-effects panel specifications only generate consistent parameter estimates under the assumption of strict exogeneity (Petersen, 2009). Therefore, we adopt another solution for dealing with endogeneity, i.e. propensity score matching (PSM), which has been used in several recent accounting studies to illustrate the sensitivity of previous multiple regression findings (Armstrong et al., 2010, 2012; Lawrence et al., 2011; Minutti-Meza, 2013). These studies highlight the effectiveness of pairing techniques in addressing concerns about structural issues in the underlying data, minimal overlap and nonlinear relations between variables that may compromise the validity of the estimates of average treatment effects in multiple regression models.

To implement the PSM approach, we first estimate the probability of selecting an able manager by employing probit regression of the $\mathrm{MA}_{\text {dummy }}$ variable against the determinants of IC disclosure. We then match, without replacement, a high-ability manager with a low-ability manager based on the closest fitted value (within 3\%) taken from the first stage of probit estimation. In this case, firms with able managers (treated group) and firms without able managers (control group) should be similar in terms of IC disclosure determinants. The results in Panel A of Table 7 indicate that treated and control firms are statistically similar in variables known to affect IC disclosure. Next, we estimate Model 1 using the matched sample. The results in Panel B of Table 7 indicate that $\mathrm{MA}_{\text {matched }}$ is significantly and negatively associated with IC at the $5 \%$ level. These findings are consistent with our main results and suggest that the possibility of endogenous relationships between MA and IC disclosure is faint.

4.4.2 Alternative measure of managerial ability. In the robustness test, we follow prior research in using the decile rank (by industry and year) of MA as an alternative specification of MA (Demerjian et al., 2012, 2013; Huang and Sun, 2017; Hesarzadeh and Bazrafshan, 2019). The results of Table 8 show that the coefficient of the alternative proxy for MA (MA-RANK) is negative and significant, which indicates the robustness of our previous findings.

\section{Discussion}

Although there are no requirements regarding IC disclosure, firms can disclose IC information for different reasons such as facilitating the prediction of their future status, determining their intrinsic value, improving their status to utilize financing, mitigating information asymmetry and reducing the cost of capital and agency costs. However, agency theory suggests that corporate owners' and management's goals do not perfectly align. As a result, managers may be involved in opportunistic activities for personal gains (Verrecchia, 1983; Dye, 1985; Mishra, 2014). In particular, agency conflicts in a less developed corporate governance environment such as Iran are intensified, which increases the potential for managerial wrongdoing (e.g. Fan and Wong, 2005); thus, qualified managers may minimize voluntary IC disclosures to serve their own interests. Also, by reducing intellectual property disclosure, capable managers in a weak corporate governance environment can misuse information related to intangible assets and make transactions based on this information without informing other investors. Consistent with the above arguments, our primary analysis shows that more capable managers reduce IC disclosure in the Iranian information environment, and a negative and significant relationship is observed between these two variables.

In addition, we examine the effect of firm performance on the relationship between MA and IC disclosure for further investigation. We find that firms with better financial performance experience a positive and significant relationship between MA and IC disclosure. It is argued that firms with better performance (more profitable) have more effective corporate governance mechanisms (Battisti et al., 2021), and therefore, managers cannot work toward opportunistic goals. This causes managers to strive for corporate goals and signal good corporate performance to the market through more voluntary disclosure (Wolk et al., 2012). 


\begin{tabular}{lrrr}
\hline $\begin{array}{l}\text { Panel A. One to one matched sample } \\
\text { Treatment }(N=119)\end{array}$ & Control $(N=119)$ & $p$-value \\
\hline FSIZE & 14.247 & 14.316 & 0.740 \\
LEV & 0.586 & 0.595 & 0.576 \\
PROFITABILITY & 0.096 & 0.083 & 0.474 \\
LNAGE & 3.578 & 3.613 & 0.369 \\
BOARDSIZE & 5.050 & 5.033 & 0.652 \\
BOARDIND & 0.688 & 0.690 & 0.930 \\
BOARDGD & 0.043 & 0.065 & 0.250 \\
FAMILY & 0.046 & 0.066 & 0.305 \\
CONOWN & 0.694 & 0.701 & 0.784 \\
PSCORE & 0.480 & 0.480 & 1.000 \\
\hline
\end{tabular}

Panel B. Regression results with propensity score matched samples

Dependent variable $=$ IC $\quad$ Coefficient

$t$-statistic

\begin{tabular}{|c|c|c|}
\hline $\mathrm{MA}_{\text {matched }}$ & $-0.070^{* *}$ & -1.98 \\
\hline FSIZE & $0.016 * * *$ & 3.76 \\
\hline LEV & $0.095^{* * *}$ & 2.33 \\
\hline PROFITABILITY & 0.085 & 1.18 \\
\hline LNAGE & -0.012 & -0.78 \\
\hline BOARDSIZE & -0.020 & -0.94 \\
\hline BOARDIND & -0.021 & -0.61 \\
\hline BOARDGD & -0.001 & -0.05 \\
\hline FAMILY & -0.068 & -1.64 \\
\hline CONOWN & $0.075^{* *}$ & 2.22 \\
\hline CONSTANT & 0.223 & 1.46 \\
\hline Industry effects & \multicolumn{2}{|c|}{ Yes } \\
\hline Year effects & \multicolumn{2}{|c|}{ Yes } \\
\hline Adj. $R^{2}$ & \multicolumn{2}{|c|}{0.251} \\
\hline$F(p$-value $)$ & \multicolumn{2}{|c|}{$3.96(0.000)$} \\
\hline Observarions & \multicolumn{2}{|c|}{238} \\
\hline
\end{tabular}

Note(s): This table reports the results of endogeneity test. See Table 1 for variable definitions $*$, ** and *** Significant at $p$-levels of less than $0.10,0.05$ and 0.01 , respectively

Table 7 . Endogeneity test

\section{Conclusion}

The voluntary disclosure of IC might be an essential tool that allows top managers to mask or overstate firm performance. Scholars link MA to firm performance outcomes and find a positive relationship between MA and firm performance. However, there is limited research on the relationship between MA and the disclosure of IC information. Using a sample of Iranian listed firms for the period 2012-2017, we find that MA is significantly and negatively associated with the overall IC disclosure and all the three components of IC (human, structural and relational capital). Our main results remain unchanged after performing several robustness analyses. Further analysis indicates that the interaction between MA and firm performance is positive and significant, showing that the negative relationship between MA and IC disclosure is less pronounced for high-performing firms.

Showing that MA is negatively associated with IC disclosure, this study contributes to the growing literature stream linking MA to corporate disclosures. Specifically, we provide evidence that capable managers increase information asymmetry as they reduce the disclosure of IC information. However, we document that MA may increase the disclosure of IC information for firms with high profitability levels. Our results demonstrate the significance of managerial characteristics in disclosing IC information, through which market participants can be informed of a firm's true value and transparency extent. Future studies 


\begin{tabular}{|c|c|c|c|}
\hline \multirow{5}{*}{$\begin{array}{l}\text { ARA } \\
30,1\end{array}$} & Dependent variable $=\mathrm{IC}$ & Coefficient & $t$-statistic \\
\hline & MA-RANK & $-0.015^{*}$ & -1.75 \\
\hline & FSIZE & $0.017^{* * * *}$ & 9.22 \\
\hline & LEV & $0.093 * * *$ & 5.48 \\
\hline & PROFITABILITY & $0.100 * * *$ & 3.30 \\
\hline \multirow{12}{*}{72} & LNAGE & -0.003 & -0.49 \\
\hline & BOARDSIZE & $-0.036^{* * *}$ & -3.46 \\
\hline & BOARDIND & -0.013 & -0.89 \\
\hline & BOARDGD & 0.005 & 0.51 \\
\hline & FAMILY & -0.027 & -1.63 \\
\hline & CONOWN & $0.049 * * *$ & 3.19 \\
\hline & CONSTANT & $0.233 * * *$ & 3.48 \\
\hline & Industry effects & \multicolumn{2}{|c|}{ Yes } \\
\hline & Year effects & \multirow{2}{*}{\multicolumn{2}{|c|}{ Yes }} \\
\hline & Adj. $R$-squared & $\begin{array}{c}0.244 \\
1413(0000)\end{array}$ & \\
\hline & $F$ ( $p$-value) & \multirow{2}{*}{\multicolumn{2}{|c|}{$\begin{array}{c}14.13(0.000) \\
1.098\end{array}$}} \\
\hline & Observations & & \\
\hline
\end{tabular}

Table 8. Note(s): This table illustrates the analyses of alternative measures of managerial ability. See Table 1 for Alternative measure of variable definitions managerial ability $*, * *$ and $* * *$ Significant at $p$-levels of less than $0.10,0.05$ and 0.01 , respectively

are encouraged to explore additional key aspects that may influence the relationship between MA and IC disclosure. Future research can also examine the effects of managers' individual characteristics, such as materialism or narcissism, on IC disclosure.

There are two major limitations in this study, therefore, the findings presented herein should be interpreted with caution. The first is the MA measure based on the MA-Score developed by Demerjian et al. (2012), which is the most widely used in prior literature. This is an approximate measure of management performance, and we cannot rule out idiosyncratic abnormal performance reflecting in this measure. The second limitation concerns the measure of IC disclosure, which is extracted from a firm's disclosure by the meta-analyzing method in this study and other studies, may not reflect all aspects of IC disclosure.

\section{Note}

1. www.Codal.ir

\section{References}

Alfraih, M.M. (2018), "Intellectual capital reporting and its relation to market and financial performance", Journal of Ethics and Systems, Vol. 34 No. 3, pp. 266-281.

Armstrong, C.S., Jagolinzer, A.D. and Larcker, D.F. (2010), "Chief executive officer equity incentives and accounting irregularities", Journal of Accounting Research, Vol. 48 No. 2, pp. 225-271.

Armstrong, C.S., Ittner, C.D. and Larcker, D.F. (2012), "Corporate governance, compensation consultants, and CEO pay levels", Review of Accounting Studies, Vol. 17 No. 2, pp. 322-351.

Baik, B., Farber, D.B. and Lee, S. (2011), "CEO ability and management earnings forecasts", Contemporary Accounting Research, Vol. 28 No. 5, pp. 1645-1668.

Bamber, L., Jiang, J. and Wang, I. (2010), "What's our style? The influence of top managers on voluntary corporate financial disclosure”, The Accounting Review, Vol. 85 No. 4, pp. 1131-1162.

Barrena-Martínez, J., López-Fernández, M. and Romero-Fernández, P.M. (2019), "The link between socially responsible human resource management and intellectual capital", Corporate Social Responsibility and Environmental Management, Vol. 26 No. 1, pp. 71-81. 
Barus, S.H. and Siregar, S.V. (2014), "The effect of intellectual capital disclosure on cost of capital: evidence from technology intensive firms in Indonesia”, Journal of Economics, Business, and Accountancy Ventura, Vol. 17 No. 3, pp. 333-344.

Battisti, E., Nirino, N., Christofi, M. and Vrontis, D. (2021), "Intellectual capital and dividend policy: the effect of CEO characteristics", Journal of Intellectual Capital. doi: 10.1108/JIC-11-2020-0354.

Bhagat, S. and Bolton, B. (2008), "Corporate governance and firm performance", Journal of Corporate Finance, Vol. 14 No. 3, pp. 257-273.

Bismuth, A. and Tojo, Y. (2008), "Creating value from intellectual assets", Journal of Intellectual Capital, Vol. 9 No. 2, pp. 228-245.

Boeker, W. (1989), "Strategic change: the effects of founding and history", Academy of Management Journal, Vol. 32 No. 3, pp. 489-515.

Boujelbene, M.A. and Affes, H. (2013), "The impact of intellectual capital disclosure on cost of equity capital: a case of French firms", Journal of Economics, Finance and Administrative Science, Vol. 18 No. 34, pp. 45-53.

Bozzolan, S., Favotto, F. and Ricceri, F. (2003), "Italian annual intellectual capital disclosure: an empirical analysis", Journal of Intellectual Capital, Vol. 4 No. 4, pp. 543-558.

Bukh, N., Nielsen, C., Gormsen, P. and Mouritsen, J. (2005), "Disclosure of information on intellectual capital in Danish IPO prospectuses", Accounting, Auditing and Accountability Journal, Vol. 18 No. 6, pp. 713-732.

Cerbioni, F. and Parbonetti, A. (2007), "Exploring the effects of corporate governance on intellectual capital disclosure: an analysis of European biotechnology companies", European Accounting Review, Vol. 16 No. 4, pp. 791-826.

Chemmanur, T.J. and Paeglis, I.I. (2005), "Management quality, certification, and initial public offerings", Journal of Financial Economics, Vol. 76 No. 2, pp. 331-368.

Chen, J. and Chen, J. (2020), "Does managerial ability affect the quality of environmental financial disclosure?", Sustainability Accounting, Management and Policy Journal, Vol. 11 No. 6, pp. 1055-1073.

Chen, Y., Podolski, E.J. and Veeraraghavan, M. (2015), "Does managerial ability facilitate corporate innovative success?”, Journal of Empirical Finance, Vol. 34 No. 1, pp. 313-326.

Cheng, M.-Y., Lin, J.-Y., Hsiao, T.-Y. and Lin, T. (2010), "Invested resource, competitive intellectual capital, and corporate performance”, Journal of Intellectual Capital, Vol. 11 No. 4, pp. 433-450.

Cruz-González, J., López-Sáez, P., Emilio Navas-López, J. and Delgado-Verde, M. (2014), "Directions of external knowledge search: investigating their different impact on firm performance in high technology industries", Journal of Knowledge Management, Vol. 18 No. 5, pp. 847-866.

Cui, H., Chen, C., Zhang, Y. and Zhu, X. (2019), "Managerial ability and stock price crash risk", AsiaPacific Journal of Accounting and Economics, Vol. 26 No. 5, pp. 532-554.

Cuozzo, B., Dumay, J., Palmaccio, M. and Lombardi, R. (2017), "Intellectual capital disclosure: a structured literature review", Journal of Intellectual Capital, Vol. 18 No. 1, pp. 9-28.

Demerjian, P., Lev, B. and McVay, S. (2012), "Quantifying managerial ability: a new measure and validity tests", Management Science, Vol. 58 No. 7, pp. 1229-1248.

Demerjian, P., Lev, B., Lewis, M. and Sarah E. McVay, S. (2013), "Managerial ability and earnings quality", The Accounting Review, Vol. 88 No. 2, pp. 463-498.

Demerjian, P., Lev, B., Lewis, M. and McVay, S. (2020), "How does intentional earnings smoothing vary with managerial ability?", Journal of Accounting, Auditing and Finance, Vol. 35 No. 2, pp. 406-437.

Dittmar, A. and Mahrt-Smith, J. (2007), "Corporate governance and the value of cash holdings", Journal of Financial Economics, Vol. 83 No. 3, pp. 599-634. 
ARA

30,1

Dumay, J. and Cai, L. (2014), "A review and critique of content analysis as a methodology for inquiring into IC disclosure”, Journal of Intellectual Capital, Vol. 15 No. 2, pp. 264-290.

Dumay, J. and Roslender, R. (2013), "Utilising narrative to improve the relevance of intellectual capital", Journal of Accounting and Organizational Change, Vol. 9 No. 3, pp. 248-279.

Dye, R.A. (1985), "Disclosure of non-proprietary information", Journal of Accounting Research, Vol. 23 No. 1, pp. 123-145.

Edvinsson, L. (2013), "IC 21 - reflections from 21 years of IC practice and theory", Journal of Intellectual Capital, Vol. 14 No. 1, pp. 163-172.

Fan, J.P.H. and Wong, T.J. (2005), "Do external auditors perform a corporate governance role in emerging markets? Evidence from East Asia”, Journal of Accounting Research, Vol. 43 No. 1, pp. 35-72.

Garanina, T. and Dumay, J. (2017), "Forward-looking intellectual capital disclosure in IPOs: implications for intellectual capital and integrated reporting", Journal of Intellectual Capital, Vol. 18 No. 1, pp. 128-148.

Goebel, V. (2019), "Drivers for voluntary intellectual capital reporting based on agency theory", Journal of Intellectual Capital, Vol. 20 No. 2, pp. 264-281.

Haji, A.A. (2015), "The role of audit committee attributes in intellectual capital disclosures", Managerial Auditing Journal, Vol. 30 Nos 8-9, pp. 756-784.

Hambrick, D. (2007), "Upper echelons theory: an update", Academy of Management Review, Vol. 32 No. 2, pp. 334-343.

Hambrick, D.C. and Mason, P.A. (1984), "Upper echelons: the organization as a reflection of its top managers", Academy of Management Review, Vol. 9 No. 2, pp. 193-206.

Hasan, M.M. (2020), "Readability of narrative disclosures in 10-K reports: does managerial ability matter?", European Accounting Review, Vol. 29 No. 1, pp. 147-168.

Hesarzadeh, R. and Bazrafshan, A. (2019), "CEO ability and regulatory review risk", Managerial Auditing Journal, Vol. 34 No. 5, pp. 571-601.

Hesarzadeh, R. and Rajabalizadeh, J. (2019), "Corporate reporting readability and informational efficiency", Asian Review of Accounting, Vol. 27 No. 4, pp. 489-507.

Hesarzadeh, R., Bazrafshan, A. and Rajabalizadeh, J. (2019), "Financial reporting readability: managerial choices versus firm fundamentals", Spanish Journal of Finance and Accounting, Vol. 49 No. 4, pp. 452-482.

Hidalgo, R., García-Meca, E. and Martínez, I. (2011), "Corporate governance and intellectual capital disclosure", Journal of Business Ethics, Vol. 100 No. 3, pp. 483-495.

Himmelberg, C., Hubbard, R.G. and Palia, D. (1999), "Understanding the determinants of managerial ownership and link between ownership and performance", Journal of Financial Economics, Vol. 53 No. 3, pp. 353-384.

Holcomb, T.R., Holmes, M. and Connelly, B. (2009), "Managerial ability as a source of resource value creation”, Strategic Management Journal, Vol. 30 No. 5, pp. 457-485.

Holland, J. (2003), "Intellectual capital and the capital market - organisation and competence", Accounting, Auditing and Accountability Journal, Vol. 16 No. 1, pp. 39-48.

Huang, X. and Sun, L. (2017), "Managerial ability and real earnings management", Advances in Accounting, Vol. 39 No. 4, pp. 91-104.

Hui, K.W. and Matsunaga, S.R. (2015), "Are CEOs and CFOs rewarded for disclosure quality?", The Accounting Review, Vol. 90 No. 3, pp. 1013-1047.

Jensen, M. and Meckling, W. (1976), "Theory of the firm: managerial behavior, agency costs and ownership structure", Journal of Financial Economics, Vol. 3 No. 4, pp. 305-360.

Jordao, R. and Almeida, V. (2017), "Performance measurement, intellectual capital, and financial sustainability", Journal of Intellectual Capital, Vol. 18 No. 3, pp. 643-666. 
Koester, A., Shevlin, T. and Wangerin, D. (2017), "The role of managerial ability in corporate tax avoidance", Management Science, Vol. 63 No. 10, pp. 3147-3529.

Kor, Y.Y. (2003), "Experience-based top management team competence and sustained growth", Organization Science, Vol. 14 No. 6, pp. 707-719.

Krippendorff, K. (1980), Content Analysis: an Introduction to its Methodology, Sage, Beverly Hills, CA.

Kristandl, G. and Bontis, N. (2007), "The impact of voluntary disclosure on cost of equity capital estimates in a temporal setting", Journal of Intellectual Capital, Vol. 8 No. 4, pp. 577-594.

Lawrence, A., Minutti-Meza, M. and Zhang, P. (2011), "Can Big 4 versus non-Big 4 differences in auditquality proxies be attributed to client characteristics?", The Accounting Review, Vol. 86 No. 1, pp. 259-286.

Li, J., Pike, R. and Haniffa, R. (2008), "Intellectual capital disclosure and corporate governance structure in UK firms", Accounting and Business Research, Vol. 38 No. 2, pp. 137-159.

Li, J., Mangena, M. and Pike, R. (2012), "The effect of audit committee characteristics on intellectual capital disclosure", British Accounting Review, Vol. 44 No. 2, pp. 98-110.

Maaloul, A. and Zéghal, D. (2015), "Financial statement informativeness and intellectual capital disclosure: an empirical analysis", Journal of Financial Reporting and Accounting, Vol. 13 No. 1, pp. 66-90.

Mangena, M., Li, J. and Tauringana, V. (2014), "Disentangling the effects of corporate disclosure on the cost of equity capital: a study of the role of intellectual capital disclosure", Journal of Accounting, Auditing and Finance, Vol. 31 No. 1, pp. 3-27.

Mashayekhi, B. and Bazaz, M.S. (2008), "Corporate governance and firm performance in Iran”, Journal of Contemporary Accounting and Economics, Vol. 4 No. 2, pp. 156-172.

Mention, A. and Bontis, N. (2013), "Intellectual capital and performance within the banking sector of Luxembourg and Belgium”, Journal of Intellectual Capital, Vol. 14 No. 2, pp. 286-309.

Minutti-Meza, M. (2013), "Does auditor industry specialization improve audit quality?”, Journal of Accounting Research, Vol. 51 No. 4, pp. 779-817.

Mishra, D.R. (2014), "The dark side of CEO ability: CEO general managerial skills and cost of equity capital”, Journal of Corporate Finance, Vol. 29 No. 1, pp. 390-409.

Muttakin, M.B., Khan, A. and Belal, A.R. (2015), "Intellectual capital disclosures and corporate governance: an empirical examination", Advances in Accounting, Vol. 31 No. 2, pp. 219-227.

Nadeem, M. (2020), "Does board gender diversity influence voluntary disclosure of intellectual capital in initial public offering prospectuses? Evidence from China", Corporate Governance: An International Review, Vol. 28 No. 2, pp. 100-118.

Oradi, J. (2021), “CEO succession origin, audit report lag, and audit fees: evidence from Iran”, Journal of International Accounting, Auditing and Taxation, In Press. doi: 10.1016/j.intaccaudtax.2021. 100414.

Oradi, J. and E-Vahdati, S. (2021), "Female directors on audit committees, the gender of financial experts, and internal control weaknesses: evidence from Iran", Accounting Forum, Vol. 45 No. 3, pp. 273-306.

Oradi, J. and Izadi, J. (2019), “Audit committee gender diversity and financial reporting: evidence from restatements”, Managerial Auditing Journal, Vol. 35 No. 1, pp. 67-92.

Oradi, J., Asiaei, K. and Rezaee, Z. (2020), "CEO financial background and internal control weaknesses”, Corporate Governance: An International Review, Vol. 28 No. 2, pp. 119-140.

Orens, R., Aerts, W. and Lybaert, N. (2013), "Customer value disclosure and cost of equity capital", Review of Accounting and Finance, Vol. 12 No. 2, pp. 130-147.

Petersen, M.A. (2009), "Estimating standard errors in finance panel data sets: comparing approaches", Review of Financial Studies, Vol. 22 No. 1, pp. 435-480.

Petty, R. and Guthrie, J. (2000), "Intellectual capital literature review: measurement, reporting and management", Journal of Intellectual Capital, Vol. 1 No. 2, pp. 155-176. 
ARA

30,1

Rahmani, A., Arefmanesh, Z. and farshi, Z. (2014), "Intellectual capital disclosure and its impact on the cost of equity capital”, Financial Management Strategy, Vol. 2 No. 3, pp. 69-94, (In Persian).

Rossi, M., Festa, G., Ch, S., Fait, M. and Papa, A. (2021), "The effects of business ethics and corporate social responsibility on intellectual capital voluntary disclosure", Journal of Intellectual Capital, Vol. 22 No. 7, pp. 1-23.

Salvi, A., Vitolla, F., Raimo, N., Rubino, M. and Petruzzella, F. (2020), "Does intellectual capital disclosure affect the cost of equity capital? An empirical analysis in the integrated reporting context", Journal of Intellectual Capital, Vol. 21 No. 6, pp. 985-1007.

Sriram, M. (2020), "Do firm specific characteristics and industry classification corroborate voluntary disclosure of financial ratios: an empirical investigation of S\&P CNX 500 companies”, Journal of Management and Governance, Vol. 24 No. 1, pp. 431-448.

Striukova, L., Unerman, J. and Guthrie, J. (2008), "Corporate reporting of intellectual capital: evidence from UK companies”, British Accounting Review, Vol. 40 No. 4, pp. 297-313.

$\mathrm{Su}$, H.Y. (2014), "Business ethics and the development of intellectual capital", Journal of Business Ethics, Vol. 119 No. 1, pp. 87-98.

Tang, Y., Qian, C., Chen, G. and Shen, R. (2015), "How CEO hubris affects corporate social (ir) responsibility”, Strategic Management Journal, Vol. 36 No. 9, pp. 1338-1357.

Tejedo-Romero, F., Rodrigues, L.L. and Craig, R. (2017), "Women directors and disclosure of intellectual capital information", European Research on Management and Business Economics, Vol. 23 No. 3, pp. 123-131.

Verrecchia, R.E. (1983), "Discretionary disclosure", Journal of Accounting and Economics, Vol. 5 No. 1, pp. 179-194.

Wolk, H.I., Dodd, J. and Rozycki, J. (2012), "Accounting theory; conceptual issues in a political and economic environment, 8th ed", Reference \& Research Book News, Vol. 27 No. 5, Ringgold.

Yermack, D. (1996), "Higher market valuation of companies with a small board of directors", Journal of Financial Economics, Vol. 40 No. 2, pp. 185-211.

Yi, A. and Davey, H. (2010), "Intellectual capital disclosure in Chinese (mainland) companies”, Journal of Intellectual Capital, Vol. 11 No. 3, pp. 326-347.

Yuan, Y., Tian, G., Lu, L.Y. and Yu, Y. (2017), "CEO ability and corporate social responsibility", Journal of Business Ethics, Vol. 157 No. 2, pp. 391-411.

Yung, K. and Chen, C. (2018), "Managerial ability and firm risk-taking behavior", Review of Quantitative Finance and Accounting, Vol. 51 No. 4, pp. 1005-1032.

\section{Further reading}

Buzby, S.L. (1975), "Company size, listed versus unlisted stocks, and the extent of financial disclosure", Journal of Accounting Research, Vol. 13 No. 1, pp. 16-37.

Li, S.T., Tsa, M.H. and Lin, C. (2010), "Building a taxonomy of a firm's knowledge assets: a perspective of durability and profitability", Journal of Information Science, Vol. 36 No. 1, pp. 36-56.

\section{Corresponding author}

Javad Rajabalizadeh can be contacted at: javad.j.rajabalizadeh@utu.fi

For instructions on how to order reprints of this article, please visit our website:

www.emeraldgrouppublishing.com/licensing/reprints.htm

Or contact us for further details: permissions@emeraldinsight.com 